\title{
KONSEP PENDIDIKAN ISLAM MENURUT PERSPEKTIF KH. ABDURRAHMAN WAHID
}

\author{
Oleh : Achmad \\ STAIS Bangkalan
}

\begin{abstract}
ABSTRAK
Pendidikan Islam merupakan sistem yang diselenggarakan dengan hasrat untuk mengajarkan ajaran dan nilai-nilai Islam dalam kegiatan pendidikan. Penelitian ini bertujuan untuk mengetahui konsep pendidikan Islam menurut KH. Abdurrahman Wahid. Dalam penelitian kepustakaan ini digunakan metode teknik analisa data kualitatif yaitu analisa data reflektif thinking, yaitu teknik analisa data dengan dengan proses pemikiran hilir mudik. dan sebagai hasil dari penelitian ini sebagai beikut, Gus Durberpendapatbahwapendidikan Islam adalah proses penanaman nilai-nilai Islam pada diri seseorang dengan cara dan sistem tertentu, sehingga terus berkembang sesuai tuntunan zaman tanpa meninggalkan tradisi umat yang telah dilakukan sejak dahulu. Salah satu metode yang digunakan beliau adalah keberagaman atau variasi, mengingat penduduk Indonesia yang majemuk secara geografis, sehingga selalu berbeda dalam menggunakan metode pendidikan Islam. Pendidikan Islam dalam perspektif Gus Dur bertujuan untuk memanusiakan manusia, karena sebagai wahana dalam memerdekakan dan pembebasan manusia, sedangan kurikulum pendidikan Islam menurut Gus Dur sebagai berikut : Pertama, orientasi pendidikan harus lebih ditekankan pada afektif dan psikomotorik, kedua, dalam proses mengajar, guru harus mengembangkan proses pembentukan karakter kemandirian, tanggungjawab, kreatif, dan inovatif pada peserta didik, ketiga, guru harusbenar-benar memahami makna pendidikan dalam arti luas, tidak hanya transfer of knowledge saja, melainkan juga harus mengikuti transfer of value and skill dan pembentukan karakter. Gus Dur menilai proses lebih penting dari pada hasil.
\end{abstract}

Kata Kunci : Konsep, Pendidikan Islam, KH. Abdurrahman Wahid 


\section{A. Pendahuluan}

Pendidikan pada hakikatnya adalah sebuah transformasi yang mengubah input menjadi output. ${ }^{1}$ Dalam artian bahwa pendidikan merupakan sebuah proses pengembangan yang dapat menghasilkan sebuah prilaku atau etika yang baik.

Muhammad Noor Syam dalam buku Sutekno 2010 menyatakan, bahwa pendidikan adalah aktivitas dan usaha manusia untuk meningkatkan kepribadiannya dengan jalan membina potensi-potensi pribadinya, yaitu pikir, karsa, cipta budi nurani dan jasmani (panca inderaserta ketrampilan-ketrampilan). ${ }^{2}$

Sedangkan Pendidikan Islam adalah usaha berupa bimbingan dan asuhan terhadap peserta didik agar kelak setelah selesai pendidikannya dapat memahami dan mengamalkan ajaran agama Islam serta menjadikannya sebagai pandangan hidup (way of life). ${ }^{3}$ Pendidikan Islam adalah sebuah bimbingan sadar terhadap jasmani-rohani peserta didik berdasarkan beberapa hukum agama Islam menuju terbentuknya kepribadian utama menurut beberapa ukuran Islam. ${ }^{4}$ Pendidikan Islam merupakan sebuah proses transformasi ilmu dan praktek yang dilakukanoleh seorang guru kepada peserta didik dalam jangka waktu yang Panjang dan terus-menerus. Disamping itu Pendidikan agama Islam adalah salah satu mata pelajaran yang wajib dipelajari, baik disekolah Negeri ataupun swasta, dari tingkatan SD hingga perguruan tinggi selalu ada pelajaran pendidikan Islam, dan semua Lembaga Pendidikan pada umumnya di Indonesia pasti memuat pelajaran ini.

Pada awalnya Pendidikan Islam hanya terpusat di pesantren, musholla dan masjid. Namun, seiring berjalannya waktu maka Pendidikan Islam sekarang sudah merata diseluruh sekolah-sekolah kota ataupun plosok desa, apalagi setelah pemerintah melambungkan gaji PNS sehingga kalimat "guru adalah pahlawan tanpa tanda jasa" di Indonesia sudah mulai luntur dan khalayak mulai melirik profesi guru karena lebih menjanjikan, meskipun terkadang tidak punya kompetensi sebagai guru.

Hal yang demikian mungkin salah satu sebab dunia pendidikan di Indonesia semakin tahun penuh dengan masalah yang komplek, khususnya dunia Pendidikan Islam yang belakangan ini mengalami berbagai kasus yang terjadi. Mulai dari adanya peserta didik yang minim dalam beretika hingga tak ada sopan santun dan tata krama. Begitu juga sebaliknya, ada seorang guru yang melakukan Tindakan kekerasan kepada peserta didik bahkan berbuat asusila, sementara pihak peserta didik tidak menerima sehingga melaporkan permasalahan tersebut kepada pihak yang berwajib. Pada akhirnya permasalahan tersebut menjadi konsumsi publik, dan bahan perbincangan yang rumit serta berlarut-larut di masyarakat umum.

Pendidikan Islam telah memasuki nusantara sejak abad ke 7 Masehi ${ }^{5}$,banyak sekali tokoh agama yangturut membantu dalam penyebaran Islam

\footnotetext{
${ }^{1}$ DepartemenAgama RI, KendaliMutu PAI,Jakarta: Depag RI,2003, 2.

${ }^{2}$ Sutekno, Filsafat Pendidikan Islam, Surabaya : Putra Media Nusantara, 2010, 11.

${ }^{3}$ Zakiah Daradjat, Ilmu Pendidikan Islam, Jakarta : Bumi Aksara, Cet. 9, 86.

${ }^{4}$ Ahmad D. Marimba, Pengantar Filsafat Pendidikan Islam, Bandung : Al-Ma'arif, 1989, 24.

${ }^{5}$ Fanani, Sejarah Pendidikan Islam, Surabaya : Menara Madinah, 2010, 80.
} 
di tanah air ini, seperti wali songo dan beberapa ulama' yang mendapat gelar pahlawan nasional, contohnya KH. Hasyim Asy'ari, KH. Dahlan, KH. Wahab Hasbullah dan lainnya.Namun ada juga salah seorang tokoh agama di era tahun dua ribuan yang memiliki intelekbilitas sangat tinggi dan pemikiran yang sangat luas, berdarah pahlawan serta selalu memiliki terobosan yang cukup unik, dia adalah KH. Abdurrahman Wahid.

KH. Abdurrahman Wahid yang lebih dikenal dengan sapaan Gus Dur adalah mantan presiden RI yang ke-empat, beliau merupakan tokoh yang terlahir di lingkungan pesantren dan para tokoh kemerdekaan, tak jarang pemikiran beliau yang ajaib selalu menimbulkan kontroversi di kalangan masyarakat, karena ketidaksampainya masyarakat dalam memahami apa yang beliau katakan dan lakukan, maka dari itu beberapa orang mengatakan bahwa Gus Dur adalah seorang wali masa kini

Muhammad Rifa'i mengemukakan bahwa pemikiran GusDurdapat dikatakan ajaib karena selalu melakukan terobosan yang unik. ${ }^{6}$ Beliau bukan hanya dikenal sebaga iulama' saja, namun juga dikenal sebagai tokoh multikultural, tokoh demokrasi, tokoh politik dan lain-lain.Gus Dur juga merupakan salah satu tokoh multi dimensi yang pernah hidup di Indonesia untuk meluruskan pandangan, memperbarui pola fikir dan memaknai arti Pendidikan Islam di Indonesia agar sesuai dengan tujuan yang tertulis dalam Al-Qur'an dan hadits.

Oleh karena itu,dasar dari penelitian ini adalah mengkaji pemikiran beliau tentang Pendidikan Islam di Indonesia, pandangan beliau terhadap dunia Pendidikan serta langkah-langkah dan perilaku beliau dalam mengaplikasikan pemikiran tersebut, baiksewaktubeliaumenjadiulamamaupun saat beliau menjabat sebagai presiden republik Indonesia. Tujuan dari penelitian ini adalah untuk memperbaiki Pendidikan Islam seutuhnya, sebagai pedoman yang seharusnya dilaksanakan oleh lembaga pendidikan agama Islam di Indonesia.

\section{B. Kajian Teori}

\section{Konsep}

Konsep adalah rancangan atau buram surat, ide atau pengertian yang diabstrakkan dari peristiwa konkrit. ${ }^{7}$ Ditinjau dari definisinya, konsep berasal dari bahasa latin "Conceptus". Dari segi subyektif adalah suatu kegiatan intelektual untuk menangkap sesuatu, dan dari segi obyektif adalah sesuatu yang ditangkap oleh kegiatan intelektual, sehingga hasil dari tangkapan manusia itu disebut konsep.

Dalam kamus besar Bahasa Indonesia konsep adalah rancangan, ide atau pengertian yang diabstrakkan dari peristiwa konkret. ${ }^{8}$ Sedangkan Berg (1991 : 8) dalam http://eprints.ung.ac.id mengemukakan bahwa konsep adalah

\footnotetext{
${ }^{6}$ Muhammad Rifa'i,GusDurBiografiSingkat, Jogjakarta:Garasi House Of Book, 12.

${ }^{7}$ Muhammad Rifa'i ,Gus Dur., 166.

${ }^{8}$ Tim Redaksi Kamus Besar Bahasa Indonesia, Kamus Besar Bahasa Indonesia, Jakarta : Balai Pustaka, 2005, ed. 3, Cet. 2, 588.
} 
abstraksi ciri-ciri sesuatu untuk mempermudah komunikasi antara manusia sehingga memungkinkan manusia berfikir. ${ }^{9}$

Dari beberapa pengertian di atas maka dapat disimpulkan bahwa konsep adalahrancangan suatu ide, ilmu pengetahuan dan abstraksi berupa penandaan atau simbolisasi dari suatu ciri khas tertentu dan terwakili dalam setiap budaya yang memungkinkan manusia dapat berkomunikasi satu sama lain dan berfikir.

\section{Pendidikam Islam}

Kamus besar Bahasa Indonesia menjelaskan bahwa pendidikan merupakansebuah proses perubahan sikap seseorang sebagai bentuk usaha mendewasakan manusia melalui upaya pengajaran dan pelatihan (proses, cara, perbuatan mendidik). ${ }^{10}$

Sedangkan pengertian pendidikan dari segi bahasa, kita hasrus melihat kepada kata Arab karena ajaran Islam itu diturunkan dalam bahasa tersebut. Kata pendidikan yang umum kita gunakan sekarang, dalam bahasa Arab adalah "Tarbiyah", dengan kata kerja "Rabba" yang berarti mendidik. ${ }^{11}$

Pengertian pendidikan juga dapat diartikan sebuah usaha dan kegiatan yang dilakukan dalam menyampaikan seruan dan ajaran kebaikan, memberi contoh, melatih keterampilan berbuat, memberi motivasi dan menciptakan lingkungan sosial yang mendukung pelaksanaan ide pembentukan pribadi. ${ }^{12}$

Brubacher dalam bukunya Modern Philoshopies of education dalam Sutekno (2010) merumuskan batasan pendidikan sebagai berikut :

"Education should be though pf as the process of mans recipracal adjusment of nature, to his fullows and to the ultematis nature of the cosmos"

Education is the organized development and equipment of all the powers of human being moral, intelektual, and physical, by and their individual and social uses, directid toward the union for their individual and social uses, directed toward the union of there activities with their creather as their final and. Education in the process in which these powers abilities, capacitiesof men which aresusciptible to habitution are profected by goods habits, by means artiscally contred and empleyed by a men to help another or himself achive the end in view". ${ }^{13}$

\footnotetext{
${ }^{9}$ http://eprints.ung.ac.id, diunduh pada tanggal 7 Desember 2017, Pukul 19.15.

${ }^{10}$ Tim Redaksi Kamus Besar Bahasa Indonesia, Kamus Besar., 263.

${ }^{11}$ Zakiah Daradjat, Ilmu Pendidikan Islam, Jakarta : Bumi Aksara, 2011, 25.

${ }^{12}$ Zakiah Daradjat, Ilmu., 27.

${ }^{13}$ John S. Brubacher, Modern Philoshophies of Education, Tokyo : Kugha Kushu Company, 1962, 20.
} 
Pendidikan merupakan usaha yang dilakukan secara sadar dan jelas memiliki tujuan,sehingga diharapkan dalam penerapannya ia tak kehilangan arah dan pijakan. ${ }^{14}$

Pendidikan merupakan pula hasil atau potensi-potensi yang dicapai oleh perkembangan manusia dan usaha lembaga-lembaga tersebut dalam mencapai tujuannya. ${ }^{15}$ Dari ulasan di atas dapat disimpulkan bahwa pendidikan adalah sebuah proses usaha seseorang dari ketidaktahuan menjadi tahu dengan terciptanya prilaku dan tingkah laku yang baik sebagai hasil dari proses usaha tersebut. Melalui pendidikan seseorang dapat memahami apa yang mereka lakukan, sehingga mengetahui mana yang baik untuk dilakukan dan mana yang kurang baik segera ditinggalkan.

Islam sendiri dalam kamus besar Bahasa Indonesia adalah sebuah agama yang diajarkan oleh Nabi Muhammad SAW, berpedoman pada kitab suci Al-Qur'an yang diturunkan ke dunia melalui wahyu Allah SWT. ${ }^{16}$ Agama sendiri merupakan sebuah ajaran dan sistem yang mengatur tata keimanan (kepercayaan) dan peribadatan Tuhan yang Maha Kuasa serta tata kaidah yang berhubungan dengan pergaulan manusia dan manusia beserta lingkungannya. ${ }^{17}$

Spencer mengatakan bahwa agama pada dasarnya berisi keyakinan akan adanya sesuatu yang mahakekal yang berada di luar intelek. ${ }^{18}$ Menurut M. Reville agama adalah daya penentu kehidupan manusia, yaitu sebuah ikatan yang menyatukan pikiran manusia dengan pikiran misterius yang menguasai dunia dan diri yang dia sadari, dan dengan hal-hal yang menimbulkan ketentuan bila terikat dengan hal tersebut. ${ }^{19}$

Dari berbagai penjelasan beberapa teori diatas, maka dapat disimpulkan bahwa Islam adalah sebuah keyakinan yang berisi ajaran dan aturan yang mengatur sebuah kehidupan manusia sebagai pedoman untuk menjalankan sebuah peribadatan, sehingga dapat membedakan baik dan buruk apa yang akan dilakukan.

Setelah mengetahui beberapa pengertian pendidikan dan Islam maka kita simpulkan bahwa pendidikan Islam adalah suatu proses ketidaktahuan seseorang menjadi tahu dengan sebuah ajaran dan sistem yang mengatur tata keimanan sebagai pedoman dalam menjalani kehidupan.

Menurut Miqdan Yaljan dalam buku Sutekno (2010), pendidikan Islam adalah usaha menumbuhkan dan membentuk manusia muslim yang sempurna dari segala aspek yang bermacam-macam : aspek kesehatan, akal,

\footnotetext{
${ }^{14}$ Armai Arief, Pengantar Ilmu dan Metodologi Prndidikan Islam, Jakarta: Ciputat Press, 2002, 15

${ }^{15}$ Sutekno, Filsafat.,11.

${ }^{16}$ Tim Redaksi Kamus Besar Bahasa Indonesia, Kamus Besar., 444.

${ }^{17}$ Tim Redaksi Kamus Besar Bahasa Indonesia, Kamus Besar., 12.

${ }^{18}$ Emile Durkhem, The Elementary Forms of The Religious Life, Jogjakarta : IRCiSoD, 2011, 50.

${ }^{19}$ Emile Durkhem, The Elementary., 56.
} 
keyakinan, kejiwaan, kemauan, daya cipta semua tingkat pertumbuhan yang dibawa oleh Islam dengan versi dan metode-metode pendidikan yang ada. ${ }^{20}$

Muhammad Fadhil al-Jamali mengemukakan bahwa pendidikan Islam adalah proses yang mengarahkan manusia kepada kehidupan yang baik dan yang menyangkut derajad kemanusiannya, sesuai dengan kemampuan dasar (fitrah) dan kemajuan ajar (pengaruh dari luar). ${ }^{21}$

Pendidikan Islam merupakan pembentukan kpribadian muslim, dengan tujuan sebuah harapan untuk menghasilkan manusia yang berguna bagi dirinya dan masyarakatnya serta senang dan gemar mengamalkan dan mengembangkan ajaran Islam dalam berhubungan dengan Allah dan dengan manusia sesamanya, dapat mengambil manfaat yang semakin meningkat dari alam semesta ini untuk kepentingan hidup di dunia kini dan di akhirat nanti. ${ }^{22}$

\section{KH. Abdurrahman Wahid}

KH. Abdurrahman Wahid adalah salah satu tokoh fenomenal yang pernah ada di negeri ini, tokoh terbesar Indonesia di penghujung abad 20 dan permulaan abad 21, yang dengan lantang menyuarakan kebenaran, jarang ada orang seberani beliau. Tidak sedikit yang membenci beliau, tetapi tidak sedikit juga orang yang mengaguminya. ${ }^{23}$

KH. Abdurrahman Wahid lebih dikenal dengan sapaan Gus Dur, beliau terlahir dari garis keturunan orang besar atau ulama yang telah diakui Indonesia secara luas.

Dari garis bapak, Gus Dur adalah putra KH. A. Wahid Hasyim, ulama perintis kemerdekaan, pahlawan nasional, dan Menteri Agama Pertama Republik Indonesia. Sedangkan KH. A. Wahid Hasyim sendiri adalah putra KH. Hasyim Asy'ari, pahlawan nasional pendiri pesantren Tebuireng dan Nahdlatul Ulama (NU).

Dari garis ibu, Gus Dur merupakan putra Ny. Hj.Sholichah Bisri, beliau adalah putri KH. Bisri Syansuri, ulama fiqih, Rais 'Aam PBNU, dan pendiri pesantren Denanyar Jombang.

Gus Dur sendiri juga pernah menyatakan bahwa ia memiliki darah keturunan Tionghoa, menurut beliau dirinya adalah keturunan dari Tan Kim Han yang menikah dengan Tan A lok, saudara kandung Raden Patah (Tan Eng Hwa), pendiri Kesultanan Demak.

Nama kecil Gus Dur adalah Abdurrahman al-Dakhil, sebuah nama yang diambil oleh ayahnya dari nama seorang perintis Dinasti Umayyah di Spanyol. Banyak sumber menyebutkan bahwa Gus Dur lahir pada 4 Agustus

${ }^{20}$ Sutekno, Filsafat., 23-24.

${ }^{21}$ Sutekno, Filsafat., 24.

${ }^{22}$ Zakiah Daradjat, Ilmu., 29-30.

${ }^{23}$ Mubarok Yasin, Fathurrahman Karyadi, Gus Dur di Mata Keluarga dan Sahabat, Jombang :

Pustaka Tebuireng, 2010, iv. 
1940, akan tetapi dalam buku yang ditulis oleh Aboe Bakar Actjeh (Jakarta : 1957) menyebutkan tanggal 4 Juli 1939.

Sejak kecil Gus Dur tinggal di pesantren Tebuireng, karena sang ayahnya adalag pengajar dan wakil pengasuh pesantren Tebuireng, sejak kecil Gus Dur dididik langsung oleh kakeknya yaitu KH. Hasyim Asy'ari dan diajari mengaji, sehingga pada usia lima tahun Gus Dur sudah lancar membaca Al-Qur'an. Pada usia empat belas tahun beliau sudah berkaca mata, hal ini menunjukkan bahwa beliau sangat suka membaca, mulai buku ilmiah sampai buku fiksi, baik berbahasa Indonesia, Arab, maupun Indonesia telah beliau baca semua. ${ }^{24}$

\section{Metode Penelitian}

Dalam penelitian ini menggunakan metode teknik analisa data kualitatif yaitu data reflektif thinking, dimana pengolahan datanya dengan proses pemikiran hilir mudik. dan untuk sumber data yang digunakan adalah sumber data primer dan sumber data sekunder.

a) Sumber data primer

Data primer adalah data yang langsung dikumpulkan oleh peneliti dari sumber pertamanya, ${ }^{25}$ berupa buku-buku yang ada kaitannya dengan GusDur yaitu paradigma ushul fiqih multikultural GusDur, biografi singkat GusDur.

b) Sumber data sekunder

Data sekunder adalah sumber bahan kajian yang digambarkan oleh bukan orang yang ikut mengalami atau yang hadir pada waktu kejadian berlangsung. ${ }^{26}$ Jadi, sumber data sekunder dalampenelitian ini adalah tulisan-tulisan yang mengkaji pemikiran-pemikiran KH. Abdurrahman Wahid, yang mendukung sumber pertama yang berupa buku-buku, skripsi, buletin/jurnal dan lain-lain yang mendukung. Sedangkananalisis yang digunakan adalah analisis data model Miles dan Huberman. Sedangkan teknik analisis yang digunakan adalah teknik analisis deskriptif yaitu mendeskripsikan konsep pendidikan Islam dari perspektif KH. Abdurrahman Wahid yang kemudian dianalisis.Langkah-langkah yang penulis lakukan adalah sebagai berikut:

a) Membaca buku berbagai biografi dan pemikiran-pemikiran KH.Abdurrahman Wahid secara cermat untuk mendapatkan pemahaman.

b) Membuat konsep yang sesuai dengan keterangan buku biografi dan pemikiran-pemikitan KH.Abdurrahman Wahid.

\footnotetext{
${ }^{24}$ Mubarok Yasin, Fathurrahman Karyadi, Gus Dur., 2-4.

${ }^{25}$ Sugiyono, Metode Penelitian Kuantitatif Kualitatif dan R\&D, Bandung : Alfabeta, 2009, Cet. 8, 137.

${ }^{26}$ Sunandi Suryabrata, Metodologi Penelitian, Jakarta: RajaGrafindo Persada, 2013, 39.
} 

c) Mendeskripsikan konsep pendidikan Islam dalam perspektif KH.Abdurrahman Wahid.
d) Menganalisis keterangan dalam buku biografi dan pemikiran-pemikitan KH.Abdurrahman Wahid.
e) Menyimpulkan hasil penelitian

\section{Hasil Penelitian}

\section{Kelahiran}

Abdurrahman Wahid lahir pada hari ke-4 dan bulan ke-8 kalender Islam (Agustus) 1940. Terdapat kepercayaan bahwa dia lahir 4 Agustus, namun kalender yang digunakan untuk menandai hari kelahirannya adalah kalender Islam yang berarti dia lahir pada 4 Sya'ban, sama dengan 7 September 1940.

Abdurrahman Wahid adalah anak pertama dari pasangan KH. Wahid Hasyim dan Nyai Solichah,nama wahid diambil sebagaimana kebanyakan dalam tradisi orang Islamabangan di Jawa, yang sering menggunakan nama ayah setelah namanya sendiri.

Dan sesuai dengan kebiasaan Arab sendiri, dia adalah Abdurrahman putra Wahid, sebagaimana ayahnya sendiri Wahid Putra Hasyim. Namun demikian, kebiasaan orang jawa, nama tersebut akhirnya mengalami perkembangan dan berbeda dengan nama resminya.

Kehadiran anak bernama Abdurrahman Wahid ini sangat membahagiakan kedua orangtuanya, karena disamping dia anak laki-laki, juga anak pertama. Dia dipenuhi oleh optimisme seorang ayah, hal ini bisa terlihat dari pemberian nama Abdurrahman Ad Dakhil, terutama kata Ad Dakhil jelas merujuk dari nama pahlawan dari dinasti Umayyah, yang secara harfiah berarti "Sang Penakluk". Sebagaimana kita ketahui dalam sejarah peradaban Islam ke Spanyol dan mendirikan peradaban yang berlangsung disana selama berabad-abad. ${ }^{27}$

\section{Masa Pendidikan}

Masa pendidikan umum yang dilakukan oleh Gus Dur dilakukan di Jakarta, dia memulai sekolah dasarnya di sekolah dasar KRIS di Jakarta Pusat. Namun, dikelas empat Gus Dur pindah kesekolah dasar Matraman Perwari dan sekolah SMP di Jogjakarta.

Proses belajar atau masa pendidikan Gus Dur dimasa sekolah dasar dan lanjutan pertamanya adalah disekolah-sekolah sekuler, dan inilah yang membedakan dirinya dengan kakek dan ayahnya yang tidak pernah mencicipi

${ }^{27}$ Grag Barton, Biografi Gus Dus, Yogyakarta: Lkis, 2003, 33. 
pendidikan sekuler, sehingga dapat dikatakan dia merupakan penanda generasi santri yang menerima pendidikan modern sejak awal.

Setelah beranjak dewasa dia belajar bahasa Arab secara sistematik, dan ketika sekolah SMEP di Jogjakarta, dia berusaha untuk mengatur bagaimana caranya dapat pergi ke Pesantren Al-Munawwir di Krapyak tiga kali. Disinilah dia belajar bahasa Arab dengan KH. Ali Ma'shum. ${ }^{28}$

Selain itu, pada masa kecil dia juga sudah berkenalan dengan dunia seni, baik dunia seni yang berada dipesantren, seperti barjanji, diba' maupun hadrah, juga berkenalan dengan musik Barat, yaitu musik klasik, terutama karya Beethoven, dari seorang teman bapaknya, Williem Iskandar Bueller.

Dari sinilah kita dapat melihat bagaimana dunia seninya Gus Dur, yang sejak kecil sudah mengenal berbagai jenis musik, baik musik khas pesantren, maupun musik Barat yang klasik, sehingga mempengaruhi sosok dirinya bagaimana dikemudian hari yang pluralis.

Di kota Jogja minat baca dan kehausan Gus Dur akan ilmu pengetahuan muncul dan semakin melesat jauh. Kota Jogja sendiri merupakan kota pelajar, dengan berbagai universitas dan banyak toko buku, buku-buku yang dimiliki kenalan gurunya dan gurunya sendiri, serta milik sang bapak kos telah dia baca, disini Gus Dur sangat mencintai buku dan selalu mengunjungi toko buku secara rutin.

Di kota Jogja ini Gus Dur juga menyukai pertunjukan wayang kulit, dia juga menggemari dan sering menonton film digedung bioskop yang tak jarang dia lakukan dengan cara mencuri waktu belajarnya. Semuanya dilakukan karena pelajaran di pesantren relatif mudah baginya tanpa perlu belajar secara serius, atau dapat dikatakan dia melanjutkan sisa kenakalannya saat kecil menuju dunia petualangannya di masa remaja.

Dari sini kita mendapatkan bagaimana dunia pertunjukan atau sandiwara yang disukai oleh Gus Dur sangat beraneka ragam, bahkan bisa dikatakan bertolak belakang, antara dunia seni modern dengan dunia seni tradisional. Oleh karena itu, dia selalu mempertahankan tradisi tanpa mau ketinggalan dengan perkembangan yang ada.

Fase belajar dari Jogja sampai ke Magelang telah meluaskan bacaannya dengan segala keragaman, mulai dari cerita silat Ko Phing Ho sampai novelnovel Barat. Dia juga mendalami beberapa karya klasik pemikir Barat dan para pelaku aktivis perubahan dunia, seperti Karl Marx dan Lenin. Untuk seukuran umurnya saat itu, membaca buku-buku tersebut bagi kita adalah hal

${ }^{28}$ Grag Barton, Biografi.,40. 
yang aneh, langka, ajaib, bahkan kontroversial, apalagi beberapa buku berbahasa inggris.

Tapi, memang demikianlah Gus Dur, selain diajar oleh guru informal yang kuat, bisa jadi Gus Dur juga diberi karunia oleh Tuhan sehingga dapat cepat memahami sebuah bacaan dan ingatan yang luar biasa tentang bacaan tersebut. Kemungkinan inilah yang menjadi dasar bagi seorang calon pemimpin di masa depan.

Setelah tamat dari SMP di Jogjakarta pada 1957, Gus Dur pindah ke Magelang, tepatnya ke pesantren Tegalrejo dibawah asuhan kiai karismatik, Kiai Khudor, disini Gus Dur belajar secara penuh dengan dunia pesantren beserta segala keilmuannya.

Proses belajar Gus Dur di Pesantren ini dilakukan selama dua tahun, yaitu sampai 1959. Di samping itu, pada saat yang sama dia juga belajar paro waktu di Pesantren Denanyar Jombang di bawah bimbingan kakeknya dari pihak ibu, yaitu kiai Bisri Syansuri. ${ }^{29}$

Setelah dua tahun belajar di pondok pesantren ini, Gus Dur melanjutkan belajar pesantrennya ke Jombang pada tahun 1959. Pondok pesantren yang dia inginkan adalah Pesantren Tambak beras, dibawah asuhan Kiai Wahab Hasbunallah.

Di pesantren ini Gus Dur melakukan hubungan secara intens dengan Kiai Wahab Hasbunallah, dari pondok pesantren ini dia mendapat dorongan untuk menjadi pengajar, bahkan pernah menjadi kepala madrasah modern.

Dari pesantren inilah minat Gus Dur mulai bertambah, tidak hanya pada studi keislaman, tetapi juga tertarik pada tradisi sufistik dan mistik dari kebudayaan dan tradisi Islam. Dari sinilah dia kemudian memiliki tradisi dan sering berkunjung ke makam-makam para wali, kiai dan ulama pada tengah malam.

Sebagaimana kakeknya Syekh Hasyim Asy'ari dan ayahnya Wahid Hasyim, yang selalu haus akan ilmu pengetahuan dan selalu merasa kurang dalam belajar ilmu pengetahuan, Gus Dur pun demikian. Untuk itu, dia melanjutkan studinya keluar negri yaitu Kairo, Baghdad dan kemudian Eropa.

Diawal studinya di Al-Azhar Kairo Gus Dur terlihat bersemangat. Namun, dia sangat kecewa karena masa keemasan Al-Azhar telah mencapai puncaknya beberapa dasa warsa sebelumnya, yaitu pada pertengahan 1960an, sehingga menurutnya tingkat pertama di universitas ini tidak menawarkan

${ }^{29}$ Grag Barton, Biografi Gus Dur., 49. 
banyak hal yang baru bagi seorang lulusan sejumlah pesantren yang baik diIndonesia.

Gus Dur merasa banyak hal yang diulang dalam studinya di Mesir, sehingga dia begitu enggan melakukan studi formalnya, dan sering tidak masuk sekolah. Dia banyak menyalurkan hobinya mengikuti pertandingan sepak bola yang banyak terdapat di Kairo, membaca di perpustakaanperpustakaan yang besar, menonton film-film Prancis dan ikut serta dalam diskusi-diskusi di beberapa kedai kopi yang sangat menarik. Disinilah, menurut Greg, Al-Azhar menjadi kekecewaan Gus Dur, dan sebaliknya Kairo sangat menyenangkan.

Untungnya, kondisi yang membosankan di Kairo tersebut, segera terobati ketika dia mendapat tawaran beasiswa di Universitas Baghdad. Pada 1960-an, Universitas Baghdad mulai berubah menjadi Universitas bergaya Eropa.

Dimasa ini, beliau mempunyai jadwal proses belajar yang padat daripada di Kairo. Namun begitu, dia masih tetap memiliki waktu untuk pergi kebioskop untuk menonton lagi film-film prancis seperti yang ditontonnya di Kairo.

Di Baghdad ini pula, dia belajar bahasa Prancis di pusat kebudayaan Prancis, karena jadwal belajar Gus Dur lebih ketat dari pada di Kairo, dia tidak dapat mengikuti diskusi-diskusi dikedai kopi sesering yang dilakukan di Kairo. Dikota ini,dia belajar Sufisme dan sering melakukan ziarah kubur ke beberapa makam para wali kelas dunia.

Di Baghdad ini pula Gus Dur belajar tentang sejarah, tradisi dan komunitas Yahudi. Dalam belajar hal ini dia bersahabat dengan Ramin, seorang pemikir Liberal dan terbuka dari komunitas kecil Yahudi Irak di Baghdad

Mereka berdua sering bertukar gagasan yang terkadang secara khusus dilakukan oleh mereka berdua saja.dari Ramin lan, ia belajar menghormati Yudaisme dan memahami pandangan agama Yahudi serta keprihatinan politik dan sosial orang-orang Yahudi yang hidup dalam diaspora sebagai kaum minoritas yang sering di siksa. ${ }^{30}$

Selama dua tahun terakhir di Baghdad, Gus Dur memfokuskan diri pada riset mengenai sejarah Islam di Indonesia. Dosen-dosennya memberikan izin kepadanya untuk banyak menulis mengenai Islam di Indonesia. Maka, dia pun membaca semua sumber dari kaum orientalis dan tulisan-tulisan orang Indonesia mengenai hal itu.

${ }^{30}$ Grag Barton, Biografi Gus Dur., 104. 
Dia benar-benar tak menduga bahwa perpustakaan Universitas Baghdad menyediakan sumber informasi yang sangat luas mengenai topik ini. Dengan memanfaatkan sumber-sumber yang kaya ini, Gus Dur menjadi seseorang yang mempunyai otoritas akademis dalam masalah ini.

Pada pertengahan 1970-an, Gus Dur menyelesaikan studi empat tahunnya di Universitas Baghdad dan pindah ke Eropa. Mula-mula dia tinggal di Belanda untuk mendapatkan kesempatan melanjutkan studinya. Dia berharap dapat memperoleh kesempatan untuk melakukan studi Pascasarjana dibidang perbandingan agama.

Awalnya dia mencoba mencari informasi mengenai hal ini di Universitas Leiden. Ketika itu dia berharap akan bisa memperoleh tempat studinya lebih lanjut. Namun, kekecewaan yang diperoleh Gus Dur karena Leiden dan seluruh Eropa tidak mengakui lembaga studi Universitas Baghdad.

Saat itu universitas-universitas Eropa menetapkan prasyarat yang mengharuskannya untuk mengulang studi tingkat sarjananya. Akhirnya, untuk mengurangi rasa kecewanya, dia berkelana selama hampir setahun di Eropa dan kemudian kembali ketanah air pada pertengahan 1971 dengan tangan kosong.

Namun demikian, dia tak patah hati. Dia menetapkan diri akan belajar dari kehidupan dan pengalamannya di Eropa. Dengan tinggal di Eropa dia mempunyai kesempatan untuk mempelajari dari tangan pertama sifat masyarakat di Belanda, Jerman dan Prancis. Dia juga berkesempatan untuk melalukan percakapan dan diskusi mengenai masyarakat dan pemikiran Barat di Eropa.

Harus diakui, kegagalannya untuk studi di Eropa membuatnya dilanda kekecewaan. Untuk menghibur dirinya, dia pulang ke Jawa pada 4 Mei 1971, kemudian menata harapannya lagi agar bisa menuntut ilmu keluar negeri. Kali ini harapannya ke Universitas McGill, Montreal, Kanada.

Besar kemungkinan harapan tersebut tercapai. Lantaran dia cerdas, tidak sukar baginya untuk mendapatkan referensi dan mentor yang dapat meyakinkan pihak Universitas itu. Belum lagi koneksi keluarganya yang mempunyai jalur ke menteri agama. Oleh karena itu, Gus Dur merasa yakin bahwa dia akan dapat memperoleh beasiswa di McGill. 
Namun, hal itu urung terjadi. Pada September 1971, Gus Dur dan Nuriyah melangsungkan pesta perkawinan dan kemudian tinggal di Jombang. Selanjutnya Gus Dur terus keliling Jawa31.

Dia berkenalan dengan LSM LP3ES di Jakarta dan kemudian secara teratur dan tiap dua minggu sekali bekerja di kantor tersebut selama beberapa hari. Apalagi peristiwa ketika dia berkeliling mengunjungi pesantren di Jawa, beliau merasa terkejut melihat besarnya serangan terhadap system nilai tradisional pesantren. Disinilah dia mengurungkan niatnya studi keluar negeri.

\section{Konsep Pendidikan Islam Perspektif Menurut KH. Abdurrahman Wahid}

Pendidikan Islam merupakan sistem yang diselenggarakan atau didirikan dengan hasratuntuk mengajarkan ajaran dan nilai-nilai Islam dalam kegiatan pendidikannya. ${ }^{32}$ Tujuan dikembangkannya Islam adalah untuk mendidik budi pekerti. Oleh karenanya,pendidikan budi pekerti atau akhlak merupakan jiwa pendidikan Islam yang menjadi satu kesatuan yang tidak terpisahkan.Dapat dipahami bahwa pengertian pendidikan Islam yang digagas oleh KH.Abdurrahman Wahid adalah proses penanaman nilai-nilai Islam pada diri seseorang dengan cara dan sistem yang selalu berubah dengan perkembangan zaman dan tetap tidak meninggalkan tradisi umat yang telah dilakukan oleh seseorang sejak dahulu.

Dari penjelasan di atas, penulis menyimpulkan bahwa pendidikan Islam adalah sebuah proses yang berlangsung terus-menerus dengan sistem dan cara yang terus berkembang sesuai dengan perkembangan zaman, akan tetapi pendidikan Islam tetap tidak boleh meninggalkan warisan peradaban nenek moyang yang dilakukan oleh para pendahulu dalam proses pendidikan.

Di antara kebiasaan yang dilakukan oleh oleh orang-orang dahulu dan sampai kini tetap dilakukan dan dipelihara di dunia pendidikan adalah misalnya seorang murid yang mencium tangan ketika menjabat tangan guru, membungkuk ketika berjalan di depan guru atau orang yang lebih tua, serta tidak berani menatap wajah gurunya dan masih banyak lagi yang lain.

Dunia pendidikan Islam yang terkemuka di Indonesia sedikit banyak mengadopsi pemikiran KH. Abdurrahman Wahid dalam pendidikannya, di antaranya pesantren Darul Ulum, Bahrul Ulum, Tebuireng Jombang. Hidayatul Mabtadi'in Kediri,Al Madinah Pasuruan, dan Tegal Rejo Jawa Tengah. Di pesantren tersebut banyak mengadopsi pemikiran $\mathrm{KH}$.

\footnotetext{
${ }^{31}$ Abdurrahman Wahid, Tabayyun Gus Dur, Pribumi Islam Hak Minoritas Reformasi Kultural, Yogyakarta:LKIS, 1998, 30.

${ }^{32} \mathrm{http}: / /$ sosioakademika.blogspoot.id/2015/08/pengertian-pendidikan-Islam.html, diakses tanggal 10 agustus 2017.
} 
Abdurrahman Wahid dan kegiatan pendidikannya menerapkan pola pengajaran yang digagas KH. Abdurrahman Wahid.

\section{Relevansi Pemikiran Gus Dur Terhadap Pendidikan Saat Ini}

Pemikiran Gus Dur sangat relevan dengan dunia pendidikan, khususnya pendidikan yang ada di Indonesia. Menurut Gus Dur, tujuan pendidikan Islam adalah memanusiakan manusia, tujuan tersebut masih dipertahankan sampai saat ini dalam dunia pendidikan di Indonesia. Artinya dengan adanya pendidikan, diharapkan manusia bebas dan terarah dalam pengembangan fitrah yang telah diberikan Allah SWT pada dirinya. Bukan malah menjadi robot yang dikendalikan oleh golongan atau segelintir orang yang mempunyai kepentingantertentu. Bahkan tidak hanya pendidikan dalam perspekif Islam saja, namun juga berlaku untuk semua agama. ${ }^{33}$

Orientasi pendidikan lebih ditekankan pada aspek efektif dan psikomotorik. Selain itu, pembelajaran aktif, kreatif dan objektif akan mengarahkan peserta didik mampu bersifat kritis dan selalu bertanya sepanjang hayat. Pemikiran beliau yang satu ini nampaknya sudah diterapkan dalam sistem pembelajaran di Indonesia saat ini juga, yakni dengan adanya metode Active Learning, dimana baik pendidik maupun peserta didik harus aktif dalam proses belajar mengajar.

Dari segi kurikulum sangat cocok diterapkan dalam pendidikan di Indonesia. Menurut beliau pendidikan seyogyanya tidak banyak mencakup Transfer OfKnowledge saja, tetapi juga harus mencakup Transfer Of Value serta pembentukan karakter. Pendidikan di Indonesia jelas sepakat dengan pemikiran tersebut, ini dibuktikan dengan munculnya K13 yang mengedepankan pendidikan berkarakter.

Pembaruan pendidikan harus terus dilakukan dan disesuaikan dengan perkembangan zaman namun tidak meninggalkan nilai-nilai agama Islam. Meski pemikiran dan konsep pendidikan dari Gus Dur ini lebih ditekankan kepada Islam, namun jika dikaji lebih dalam, semua pemikiran serta konsep beliau mengenai pendidikan tersebut masihlah umum. Semua yang beliau sajikan ini dapat pula diterapkan dalam pendidikan-pendidikan diluar konteks Islam.

\section{Analisis Pemikiran KH.Abdurrahman Wahid}

Dari hasil telaah kami terhadap sumber-sumber bacaan yang dijadikan rujukan utama, dapat diketahui bahwa pendekatan yang digunakan Gus Dur dalam menampilkan citra Islam pada masyarakat adalah dengan pendekatan

\footnotetext{
${ }^{33}$ Nur Alam Bakhtiar, Keistimewaan Gus Dur, Jakarta: Kultura GPPG, 2008, 36.
} 
sosio-kultural, yang mengutamakan aktivitas budaya dalam konteks pengembangan lembaga-lembaga menuju transformasi sistem sosial ${ }^{34}$.

Hal itu dimaksudkan dengan aktivitas-aktivitas budaya seperti sedekah yaitu orang-orang berkumpul di rumah seseorang dengan tujuan untuk bersilaturrahim dan ketika di rumah tersebut yang punya rumah menyampaikan hajat dan tujuan tertentu, biasanya orang-orang diminta membaca yassin, maulidad diba', al-barjanji dan lain-lain.

Saatini sudah banyak ajaran peninggalan agama Hindu yang mulai ditinggalkan seperti sesaji, bunga-bunga dan lain-lain. Hal ini menunjukkan aktivitas budaya yang digagas Gus Dur sudah mengalami tranformasi kearah yang lebih baik, yaitu sistem sosial yang sudah mulai tertata sesuai ajaran Islam.

Adapun pemikiran Gus Dur mengenai pendidikan merupakan hasil perpaduan yang diadaptasikan dari lingkungan pesantren dan sekolah-sekolah modern yang pernah dia singgahi. Gus Dur mencoba memadukan antara pendidikan Islam tradisional yang diterapkan dipesantren dengan pendidikan disekolah modern.

Hal itu dapat kita temui di pesantren-pesantren salaf seperti Darul Ulum, Bahrul Ulum Jombang, Hidayatul Mubtadi Kediri yang tetap memelihara ke tradisionalannya, namun tetap tidak menjadikannya ketinggalan zaman. Seperti pengajian sorogan yaitu santri mengaji bergiliran kepada seorang ustadz. Pengajian kitab kuning yaitu ustadz membaca kitab, beserta penjelasannya dengan bahasa jawa sedangkan santri diam sambil mendengar dan mencatat hal-hal yang penting yang disampaikan oleh ustadz tersebut, semua itu dengan menggunakan bahasa jawa. Sedangkan pengajian tersebut dilaksanakan di sekolah dan lembaga pendidikan modern. Mungkin yang membedakan hanya waktunya saja, dimana pengajian kitab kuning dilakukan habis subuh atau habis isya' sehingga tidak berbenturan dengan waktu pendidikan formal di pagi ataupun siang hari.

Hal ini sebagai bukti dari pemikirannya mengenai konsep pendidikan Islam yang dapat mengadopsi pemikiran barat modern, dengan tidak meninggalkan esensi dari ajaran Islam dan identitas Islam yang tetap dijadikan pegangan utama. Semuanya merupakan penyesuaian dengan perkembangan zaman yang semakin kompleks, terutama dalam dunia pendidikan terlebih di Indonesia yang penduduknya majemuk.

Secara garis besar pemikiran Gus Dur lebih terbuka, hal ini sebagai hasil dari pengalamannya selama mengembara mencari ilmu. Gus Dur melalui pemikirannya, mencoba memformulasikan konsep pendidikan, dia

${ }^{34}$ Ahmad Rifa'I, Gus Dur Biografi Singkat., 10. 
menekankan pentingnya proses dari pada hasil, sehingga hasil akhir dari sebuah perjuangan bukan hanya status sosial, namun yang terpenting adalah esensi dari ilmu yang dimiliki. ${ }^{35}$

Sebagai intelektual Sunni tradisional pada umumnya, Gus Dur membangun pemikiran melalui paradigma Sunni klasik. Oleh karena itu yang menjadi kepedulian utamanya minimal menyangkut tiga hal. Pertama, Refitalisasi khasanah Islam tradisional Ahli Sunnah Wal Jamaah. Kedua, ikut berkiprah dalam wacana modernitas. Ketiga, berupaya melakukan pencarian jawaban atas persoalan konkrit yang dihadapi umat Islam Indonesia. Corak pemikiran Gus Dur yang liberal dan inklusif sangat dipengaruhi oleh penelitiannya yang panjang terhadap khasanah pemikiran Islam tradisional shingga menghasilkan reinterpretasi dan kontekstualisasi.

\section{Faktor-Faktoryang Mempengaruhi Pemikiran KH. Abdurrahman Wahid}

Secara garis besar pemikiran Gus Dur dipengaruhi oleh 2 faktor, yaitu internal dan eksternal. Faktor internal adalah faktor dari dalam pribadi Gus Dur sendiri, sedangkan faktor eksternal adalah faktor yang merangsang dan mempengaruhi pemikiran beliau. ${ }^{36}$

a) Faktor internal

Dari garis keturunan, KH. Abdurrahman Wahid adalah orang yang punya darah biru, dalam artian dari bapak maupun ibu GusDur, keduanya adalah orang yang memiliki ilmu dan gelar. Ayahnya KH. Wahid Hasyim adalah seorang ulama dan juga tokoh pahlawan kemerdekaan, sedangkan ibunya nyai Sholikah putri dari kyai Bisri Sansuri seorang tokoh yang memperjuangkan pendidikan Islam di pesantren dan ikut mendirikan pesantren Bahrul Ulum tambak beras jombang.

Melihat silsilah tersebut kiranya wajar saja jika Gus Dur mewarisi bakat, mental, dan pemikiran orang-orang besar. Kalau seseorang keturunan Nabi Muhammad SAW bergelar habib maka di jawa, orangorang keturunan kyai atau ulama mempunyai gelar Gus. Hal ini, untuk memberikan penghormatan kepada orang tua mereka yang telah berjasa bagi masyarakat luas. ${ }^{37}$

Selain itu, faktor internal yang mempengaruhi pemikiran Gus Dur adalah kerakusan beliau dalam ilmu pengetahuan, beliau rela berkeliling ke eropa demi mencari ilmu yang menurutnya baru dan belum dia

\footnotetext{
${ }^{35}$ Muhammad Rifa'i, Gus Dur Biografi Singkat., 23.

${ }^{36}$ Moh. Dahlan, Paradigma Ushur Fiqh Multikultural Gus Dus, Bengkulu: IAIN Bengkulu Pres, 2013, 23.

${ }^{37}$ Moh. Dahlan, Paradigma., 13.
} 
pelajari di Indonesia. Karena ilmu Agama Islam sudah banyakdia pelajari di pesantren-pesantren terkemuka dan bimbingan orang tuanya. Faktor inilah yang membuatnya sering berganti-ganti guru dan tempat belajar selama di luar negeri.

b) Faktor eksternal

Diantara faktor eksternal yang mempengaruhi pemikiran Gus Dur adalah banyaknya teman Gus Dur yang berasal dari Agama Non Islam, bahkan sejak kecil Gus Dur sudah kenal dengan orang Non Islam. Di tambah lagi ketika beliau belajar di eropa, banyak beberapa teman dan guru yang mengajak berdialog tentang pluralisme Agama.

Selanjutnya faktor yang mempengaruhi pemikiran beliau adalah hobinya membaca buku,hampir semua perpustakaan di mana dia belajar telah dikunjunginya, seperti perpustakaan Universitas Al-Azhar Kairo Mesir dan Universitas Baghdad Iraq. Buku-buku yang dia baca tidak selalu tentang Islam, tetapi lebih luas mengenai perbandingan Agama sosial kemanusiaan, sejarah, dan lain-lain.

Dari hobi membaca buku inilah yang mengakibatkan syaraf matanya terganggu, sehingga semakin lama penglihatannya mulai kabur, dan akhirnya beliau menjadi buta. Walaupun begitu banyak orang berpendapat bahwa penglihatan mata hati Gus Dur lebih tajam dari penglihatan mata orang yang normal.

Faktor terakhir yang mempengaruhi pemikiran KH. Abdurrahman Wahid adalah pengalaman beliau berkeliling pesantren di Indonesia daneropa, disana Gus Dur banyak bertemu dengan orang-orang yang memberinya pengalaman baru,beliau juga tidak pernah lama tinggal di suatu tempat untuk belajar.

Gus Dur lahir di Jombang, kemudian pindah ke Jakarta, lalu pindah ke Yogyakarta, ke Malang dan kembali lagi ke Jombang, dan setelah tidak lama tinggal di Jombang Gus Dur melanjutkan perjalanan menuntut ilmunya ke Mesir, setelah dua tahun disana beliau tidak kerasan sehingga pindah ke Universitas Baghdad Irak. Setelah lulus, beliau berkeliling eropa mulai dari belanda, perancis dan terakhir jerman sebelum akhirnya Gus Dur kembali lagi ke Indonesia.

Dari perjalanan panjang yang dijalani Gus Dur selama belajar di Indonesia dan eropa,beliau banyak mendapat pelajaran dan pemahaman baru, mulai dari bahasa yang berbeda, adat budaya, hingga pengetahuan agama yang berbeda, sehingga pemikiranya lebih luas, umum dan berlaku di mana saja. Terutama pemikiran beliaudalam masalah pendidikan Islam, yaitu perpaduan antara pemikiran timur klasik, barat 
modern yang dikemas dalam ruang lingkup Islam Arab sebagai tempat diturunkannya Agama Islam. ${ }^{38}$

\section{Aplikasi Pendidikan Islam KH. Abdurrahman Wahid terhadap Keluarga, Kerabat, maupun Rakyat Indonesia ketika Menjabat Sebagai Presiden}

Pada garis besar, Gus Dur mengaplikasikan pendidikan Islam kepada keluarganya hampir sama yaitu tidak banyak berteori akan tetapi lebih banyak praktek,apalagi ke-empat anak Gus Dur adalah perempuan, sehingga beliau lebih banyak mencontohkan dari perilaku sehari-hari.

Ke-empat anaknya mempunyai Basic keilmuan masing-masing, seperti anak pertamanya Yeni Wahid yang seorang politikus, beliau hanya berpesan kepada Yeni agar jangan sampai salah niat dalam berpolitik. ${ }^{39}$

Sedangkan anak kedua dan ketiga Gus Dur tidak setenar Yeni Wahid, keduanya lebih memilih menjadi pribadi biasa namun tetap memegang petuah ayahnya yang selalu menyuruh mereka beraktivitas sesuai kemampuan.

Anak ke-empat Gus Dur Inayah Wulandari lebih dikenal sebagai penulis yang banyak menulis puisi dan pemikiran Gus Dur, namun dalam dirinya tetap memegang ke jejang ayahnya agar menjadi manusia yang bermanfaat bagi orang lain. Dikalangan sahabat, Gus Dur termasuk orang yang mudah memaafkan, hal ini yang menjadikannya dikenal banyak musuh dan kawan, karena beliau tidak takut berpendapat atau mengkritik seseorang, walau demikian tidak jarang beliau lebih dahulu berkunjung atau bersilaturahim ke tempat orang tersebut.

Hal tersebut dapat kita lihat dari pertemanan dengan soeharto, yang walaupun di depan publik Gus Dur mengkritik tetapi di belakang beliau sering terlihat berkunjung ke rumah soeharto. Beliau selalu memaafkan kesalahan sahabat-sahabatnya yang tidak jarang berbeda pendapat dengannya. Hal itu adalah bentuk pendidikan Islam yang ditawarkan GusDur melalui sahabat-sahabatnya bahwa kita adalah saudara, apalagi sesama umat Islam harus saling memaafkan dan saling bersilaturahim.

Ketika menjadi presiden, kebijakan Gus Dur mengenai pendidikan Islam dapat kita pelajari dari kebijakan beliau yang meliburkan kegiatan belajar di sekolah formal hampir sebulan penuh. Beliau berpendapat bahwa dalam keadaan puasa kegiatan belajar di sekolah tidak akan efektif, beliau hanya mengganti dengan kegiatan pondok romadhon, dimana siswa diajak

\footnotetext{
${ }^{38}$ Moh. Dahlan, Paradigma., 15.

${ }^{39}$ Armai Arief, Pengantar Ilmu dan Metodologi Pendidikan Islam., 18.
} 
menjadi santri untuk belajar Agama dalam beberapa hari. Hal ini, harusnya dikembangkan oleh lembaga-lembaga pendidikan saat ini.

Namun demikian, kebijakan Gus Dur tersebut menimbulkan polemik di masyarakat, ada yang setuju dan ada juga yang kurang setuju. Akhirnya,pemerintah sekarang melanjutkan gagasan Gus Dur tentang pondok romadhon dan tetap melaksanakan kegiatan belajar mengajar di sekolah dengan pengurangan waktu jam belajar. ${ }^{40}$

Selain itu, kebijakan beliau yang menunjukkan pemikiran Islam adalah penyamarataan suku, ras, dan golongan, hal ini dapat kita lihat dari kebijakan beliau mengenai diskriminasi PKI dengan mencabut pembatasan hak-hak bagi mantan anggota dan keluarga PKI.

Pergantian namairian jaya menjadi papua, dan ujung padang menjadi makasar, dapat dipahami bahwa GusDur memandang rakyat Indonesia adalah sama di mata Tuhan, hanya ketaqwaan yang membedakan. Hal ini sesuai dengan firman Allah dalam Al-Qur'an bahwa Allah tidak melihat dari kedudukan dan hartamu melainkan dari hati dan kekuatan Agamamu.

Dengan kebijakan tersebut banyak orang-orang non muslim yang mengagumi Gus Dur, bahkan dari agama kong hu chu membuat patung untuk Gus Dur sebagai penghargaan kepada beliau atas jasa-jasanya yang peduli terhadap kaum minoritas di Indonesia. ${ }^{41}$

\section{Penutup}

\section{Kesimpulan}

Dilihat dari corak gagasan dan pemikirannya, tampak bahwa Gus Dur dapat dikategorikan sebagai pemikiran multi warna, karena dalam pemikirannya terdapat gagasan-gagasan yang unik dan dibangun atas dasar pandangan keagamaan, kemoderenan dan kerasionalan, sehingga membawanya menjadi orang yang memiliki ultradisional, rasional, liberal, sekaligus kultural.

Gagasan dan pemikirannya dalam bidang pendidikan secara signifikan berkisar pada modernisasi pesantren, mulai dari visi, misi, tujuan kurikulum, manajemen dan kepemimpinan yang ada di pesantren harus diperbaharui sesuai dengan perkembangan zaman era globalisasi.

Selain itu, Gus Dur ternyata bukan seorang aktivis gerakan sosialdan politik semata, namun beliau seorang intelektual dan pemikir cerdas yang

${ }^{40}$ Zakiah drajat, Ilmu Pendidikan Islam., 17.

${ }^{41}$ Ibid.,20. 
Jurnal Keislaman, Vol. 1, No. 2, September

pemikiranya sejalan dengan pemikir-pemikir besar lainnya. Bahkan, di Indonesia maupun kalangan internasional, meski dia tak pernah belajar didunia akademik yang terdepan dalam ilmu-ilmu sosial, tetapi dalam pemikirannya GusDur mampu mengembangkan ilmu keagamaan yang dia miliki. 


\section{DAFTAR PUSTAKA}

Abdurrahman Wahid, Tabayyun Gus Dur, Pribumi Islam Hak Minoritas Reformasi Kultural, Yogyakarta: LKIS, 1998

Ahmad D. Marimba, Pengantar Filsafat Pendidikan Islam, Bandung : Al-Ma'arif, 1989

Armai Arief, Pengantar Ilmu dan Metodologi Prndidikan Islam, Jakarta: Ciputat Press, 2002

DepartemenAgama RI, KendaliMutu PAI,Jakarta: Depag RI, 2003

Emile Durkhem, The Elementary Forms of The Religious Life, Jogjakarta : IRCiSoD, 2011

Fanani, Sejarah Pendidikan Islam, Surabaya : Menara Madinah, 2010

http://eprints.ung.ac.id, diunduh pada tanggal 7 Desember 2017, Pukul 19.15.

http://sosioakademika.blogspoot.id/2015/08/pengertian-pendidikan-Islam.html, diakses tanggal 10 agustus 2017

John S. Brubacher, Modern Philoshophies of Education, Tokyo : Kugha Kushu Company, 1962

Moh. Dahlan, Paradigma Ushur Fiqh Multikultural Gus Dus, Bengkulu: IAIN Bengkulu Pres, 2013

Mubarok Yasin, Fathurrahman Karyadi, Gus Dur di Mata Keluarga dan Sahabat, Jombang : Pustaka Tebuireng, 2010

Muhammad Rifa'i,GusDurBiografiSingkat, Jogjakarta: Garasi House Of Book, 2010

Nur Alam Bakhtiar, Keistimewaan Gus Dur, Jakarta: Kultura GPPG, 2008

Sugiyono, Metode Penelitian Kuantitatif Kualitatif dan R\&D, Bandung : Alfabeta, Cet. 8, 2009

Suharsimi Arikunto, Prosedur Penelitian Suatu Pendekatan Praktek, Jakarta: Rineka Cipta, Cet. Ke-12, 2008

Sunandi Suryabrata, Metodologi Penelitian, Jakarta: RajaGrafindo Persada, 2013

Sutekno, Filsafat Pendidikan Islam, Surabaya : Putra Media Nusantara, 2010

Tim Redaksi Kamus Besar Bahasa Indonesia, Kamus Besar Bahasa Indonesia, Jakarta : Balai Pustaka, ed. 3, Cet. 2, 2005

Zakiah Daradjat, Ilmu Pendidikan Islam, Jakarta : Bumi Aksara, Cet. 9, 2011 